\section{'Golden Eye Cream': A Large-seeded, High-yielding, Early-maturing Southernpea for the Fresh Market and Home Garden}

\author{
J. Creighton Miller Jr. ${ }^{1}$ and Douglas C. Scheuring \\ Department of Horticultural Sciences, MS 2133, Texas A\&M University, \\ College Station, TX 77843-2133
}

Additional index words. Vigna unguiculata, plant architecture, disease resistance, root knot nematode resistance, Meloidogyne incognita

'Golden Eye Cream' is a unique, largeseeded, cream-type southernpea [Vigna unguiculata (L.) Walp.] released by the Texas Agricultural Experiment Station in 2006. The name describes the appearance of the pea. It was developed for the fresh market and home garden trades possibly to replace some of the small-seeded creams. It does not appear to be suitable for canning. Generally, 'Golden Eye Cream' matures at least 10 d earlier than 'White Acre' and about the same or slightly earlier than 'Early Acre' and is higher yielding than both, especially at narrow-row spacing. 'Golden Eye Cream' consistently produces a higher percent shell-out (66\% to $69 \%)$ than 'White Acre' or 'Early Acre'. It exhibits a high level of resistance to root knot nematode. 'Golden Eye Cream' resists lodging and pod shattering.

\section{Origin}

'Golden Eye Cream' was derived from a cross made in the greenhouse at College Station, Tex., in the fall of 1984. The parents (Fig. 1) were TX17032 ( + ), an advanced breeding line from the Texas program, and US432 (ô), released as germplasm by the U.S. Dept. of Agriculture, Agricultural Research Service in 1988 (Fery and Dukes, 1990). The parents of TX17032 were $\mathrm{TVu} 4534$, a breeding line obtained from the International Institute of Tropical Agriculture, and NCP III a land race collected by the senior author in Nigeria. The $F_{1}$ was selfed in the greenhouse in the spring of 1985 to produce $F_{2}$ seed. In summer 1985 , a single-plant selection was made from the segregating $F_{2}$ population and assigned the breeding line number TX56061BRE. Single-plant selections were made from $\mathrm{F} 3$ and F4 rows in the summers of 1986 and 1987. Selection was based on the plant's superior

Received for publication 6 June 2005. Accepted for publication 14 July 2006.

${ }^{1}$ To whom reprint requests should be addressed; email jcmillerjr@tamu.edu. architecture, pod location, and high yield of large, attractive peas. Row selections were made for four subsequent cycles $\left(\mathrm{F}_{5}-\mathrm{F}_{8}\right)$ to ensure uniformity and stability of the line. No variants have been observed in 'Golden Eye Cream'. Seed was increased in Lubbock and provided to the Texas Foundation Seed Service for further increase. 'Golden Eye Cream' was entered in the Texas statewide cowpea testing program with locations near Weslaco, College Station, Temple, Overton, and Lubbock (data not shown) and as an entry in the 1991, 1992, and 1994 Regional Southernpea Cooperative Trials (Table 1.). It has also undergone commercial evaluation by several truck farm operations, where it has been very well received.

\section{Description}

Because of its uniqueness, it is difficult to compare 'Golden Eye Cream' with other cream cultivars. 'Golden Eye Cream' has a distinct plant architecture, with a plant habit similar to 'Texas Pinkeye Purple Hull' and a plant size similar to 'California Blackeye 46'. The plant's erect growth habit, which resists lodging, lends itself to narrow-row spacing and to mechanical harvest (both fresh machine harvest and direct combining of dry seed). The stems are green with compact foliage and light-green leaves, which are glossy and more smooth than blistered. There is no purple pigmentation on the stems, branches, or petioles; however, a very light pigmentation can be noticed on peduncles and pedicels just before senescence. First flowering is generally observed about $45 \mathrm{~d}$ after planting, $\approx 10 \mathrm{~d}$ earlier than 'White Acre' (Kuhn et al., 1984), a leading creamtype commercial cultivar. The flowers are white with a light-yellow area on the interior lower central portion of the standard petal and, when tested for anthocyanins with $1 \% \mathrm{HCl}$, are tinged. The straight pods with a slight bend near the attachment point are scattered above the foliage and average $22 \mathrm{~cm}$ long and $69 \mathrm{~mm}$ wide (Fig. 2 ). The dry pods resist seed shattering. At green-shell maturity, slight to deep constrictions are noted on the dull silver green pods, which are straw-color when dry (Fig. 3). One of the unique features of 'Golden Eye Cream' is the large seed size, $\approx 32 \mathrm{~g} / 100$ seed, compared with $\approx 13 \mathrm{~g} / 100$ seed for 'Early Acre' and $\approx 20 \mathrm{~g} / 100$ seed for 'California Blackeye 46' (considered a medium-large seed in the industry). There are an average of 13 seeds per pod; a typical seed measures $11 \mathrm{~mm}$ long and $6 \mathrm{~mm}$ wide in the dry stage. When dry, the 'Golden Eye Cream' seed are slightly kidney to ovate shaped with a smooth, white seedcoat. The hilar eye is medium-small, buff or clay (gold) in color, and incomplete with a coffee-color hilum ring. During the fresh stage, the seed is large and light green in color, with no apparent eye.

'Golden Eye Cream' has exhibited a high level of resistance to root knot nematode in greenhouse and field tests (Dukes and Fery, 1993). Root knot is a major cowpea root disease incited by several species of root knot nematode of the genus Meloidogyne, in this case $M$. incognita Chitwood Race 1 . Like most cowpea cultivars, 'Golden Eye Cream' is susceptible to powdery mildew (Erysiphe polygoni DC), cercospora leaf spot (Cercospora spp.), and bacterial blight (Xanthamonas campestris). Lesser cornstalk borer (Elasmopalpus lignosellus), thrip (Frankliniella williamsi), cowpea aphid (Aphis craccivora), serpentine leaf miner (Liriomyza trifolii), cowpea curculio (Chalcodermus aeneus), and stink bug (Nezara viridula) have been observed on 'Golden Eye Cream'. 
Table 1. Results from the 1991, 1992, and 1994 Regional Southernpea Cooperative Trials comparing 'Golden Eye Cream' with the control cultivars 'Pinkeye Purple Hull BVR' (PEPH-BVR), and 'White Acre' or 'Early Acre'.

\begin{tabular}{|c|c|c|c|c|c|c|c|c|c|}
\hline Cultivar & $\begin{array}{l}\text { Days to } \\
\text { maturity }\end{array}$ & $\begin{array}{c}\text { Shell-out } \\
(\%)\end{array}$ & $\begin{array}{c}\text { Imbibed yield } \\
\left(\mathrm{kg} \cdot \mathrm{ha}^{-1}\right)^{\mathrm{z}}\end{array}$ & $\begin{array}{c}\text { Virus } \\
\text { symptoms }^{\mathrm{y}}\end{array}$ & $\begin{array}{l}\text { Leaf miner } \\
\text { ratings }^{\mathrm{y}}\end{array}$ & $\begin{array}{l}\text { Root knot } \\
\text { gall index }\end{array}$ & $\begin{array}{l}\text { Root knot } \\
\text { egg index }\end{array}$ & $\begin{array}{l}\text { Curculio } \\
\text { no. } \text { stings }^{\mathrm{x}}\end{array}$ & $\begin{array}{l}\text { Stink bug } \\
\text { no. stings }^{\mathrm{x}}\end{array}$ \\
\hline \multicolumn{10}{|l|}{1991} \\
\hline Golden Eye Cream & $66 \mathrm{~b}$ & $69 \mathrm{a}$ & 3439 a & $4.0 \mathrm{~b}$ & 3.5 & $1.4 \mathrm{c}$ & $1.3 \mathrm{c}$ & $8.0 \mathrm{c}$ & $4.5 \mathrm{~b}$ \\
\hline PEPH-BVR & $65 \mathrm{~b}$ & $57 \mathrm{~b}$ & 3381 a & $3.3 \mathrm{c}$ & 3.6 & $3.6 \mathrm{~b}$ & $3.3 \mathrm{~b}$ & $86.8 \mathrm{a}$ & $6.3 \mathrm{~b}$ \\
\hline White Acre & $78 \mathrm{a}$ & $57 \mathrm{~b}$ & $2402 \mathrm{~b}$ & $4.8 \mathrm{a}$ & 4.0 & $4.6 \mathrm{a}$ & $4.4 \mathrm{a}$ & $46.3 \mathrm{~b}$ & $13.3 \mathrm{a}$ \\
\hline Average & 70 & 61 & 3075 & 4.0 & 3.7 & 3.2 & 3.0 & 47.0 & 8.0 \\
\hline \multicolumn{10}{|l|}{1992} \\
\hline Golden Eye Cream & $70 \mathrm{~b}$ & $69 \mathrm{a}$ & $2290 \mathrm{~b}$ & $2.0 \mathrm{a}$ & 1.3 & $1.3 \mathrm{c}$ & $1.2 \mathrm{c}$ & $30.5 \mathrm{a}$ & $2.8 \mathrm{a}$ \\
\hline PEPH-BVR & $67 \mathrm{~b}$ & $59 \mathrm{~b}$ & $2896 \mathrm{a}$ & $3.0 \mathrm{a}$ & 3.8 & $2.5 \mathrm{~b}$ & $2.4 \mathrm{~b}$ & 29.8 a & $6.5 \mathrm{a}$ \\
\hline White Acre & $80 \mathrm{a}$ & $57 \mathrm{~b}$ & $1774 \mathrm{c}$ & $2.0 \mathrm{a}$ & 1.0 & $4.5 \mathrm{a}$ & $4.4 \mathrm{a}$ & $44.8 \mathrm{a}$ & $0.0 \mathrm{a}$ \\
\hline Average & 72 & 62 & 2320 & 2.3 & 2.0 & 2.8 & 2.7 & 35.0 & 3.1 \\
\hline Cultivar & $\begin{array}{l}\text { Days to } \\
\text { maturity }\end{array}$ & $\begin{array}{c}\text { Shell-out } \\
(\%)\end{array}$ & $\begin{array}{c}\text { Imbibed yield } \\
\left(\mathrm{kg} \cdot \mathrm{ha}^{-1}\right)^{\mathrm{z}}\end{array}$ & $\begin{array}{c}\text { Virus } \\
\text { symptoms }^{\mathrm{y}}\end{array}$ & $\begin{array}{c}\text { Xanthamo } \\
\text { nas ratings }\end{array}$ & $\begin{array}{l}\text { Root knot } \\
\text { gall index }\end{array}$ & & & \\
\hline \multicolumn{10}{|l|}{1994} \\
\hline Golden Eye Cream & $72 \mathrm{a}$ & $66 \mathrm{a}$ & $2840 \mathrm{a}$ & $2.0 \mathrm{a}$ & 3.0 & $1.1 \mathrm{c}$ & & & \\
\hline PEPH-BVR & $68 \mathrm{a}$ & $64 \mathrm{a}$ & $2823 \mathrm{a}$ & $2.0 \mathrm{a}$ & 1.0 & $3.1 \mathrm{~b}$ & & & \\
\hline Early Acre & $70 \mathrm{a}$ & $58 \mathrm{~b}$ & $2006 \mathrm{~b}$ & $1.0 \mathrm{a}$ & 1.0 & $4.7 \mathrm{a}$ & & & \\
\hline Average & 70 & 63 & 2556 & 1.7 & 1.6 & 3.0 & & & \\
\hline
\end{tabular}

${ }^{\mathrm{z}}$ Average of 11 locations in Alabama, Arkansas, Louisiana, Missouri, South Carolina, Tennessee, and Texas. Mean separation within columns by Student-Newman-Keuls multiple range test, $P \leq 0.05$.

${ }^{\mathrm{y}} 1=$ no symptoms to $5=$ severe infection.

${ }^{\mathrm{x}}$ Stings counted on peas shelled from 25 pods/plot.

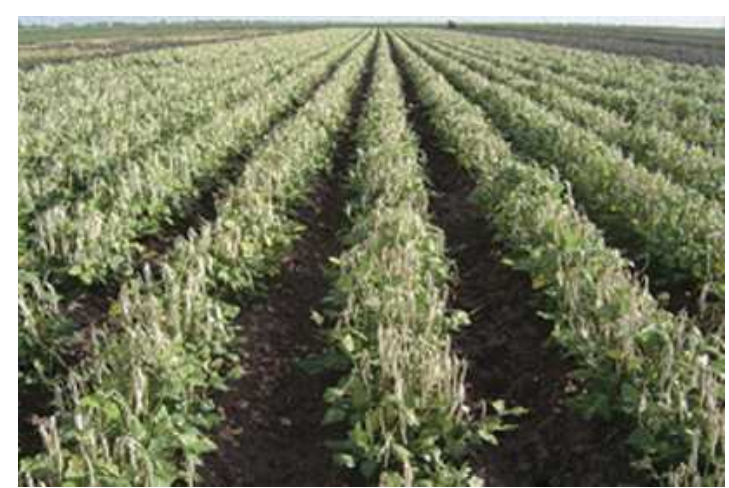

Fig. 2. Mature crop of 'Golden Eye Cream' planted in 100-cm rows.

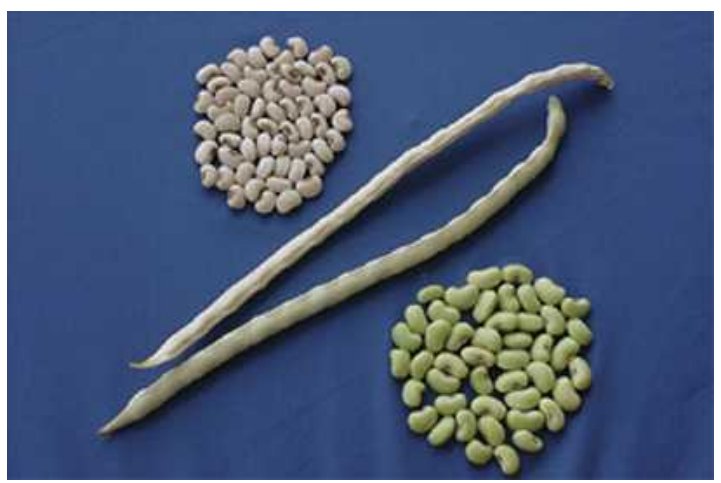

Fig. 3. Dry seed and pod (upper) and fresh pod and seed (lower) of 'Golden Eye Cream'.

'Golden Eye Cream' yield has been rated outstanding in numerous trials throughout Texas and in the Regional Southernpea Cooperative Trials (Table 1). The yield gener- ally has been significantly higher than that of 'White Acre' or 'Early Acre' (Morelock et al., 1992), especially when planted in narrow rows. In the 1991, 1992, and 1994 Regional Southernpea Cooperative Trials, 'Golden Eye Cream' generally produced a higher yield at all 12 locations across seven states than the cream control cultivars 'White Acre' and 'Early Acre', and was yield equivalent to the pinkeye control, 'Pinkeye Purple Hull-BVR' (Kuhn et al., 1984). The 1991, 1992, and 1994 Regional Southernpea Cooperative Trial results from three narrow-row spacing sites at Kibler, AR $(46 \mathrm{~cm})$, Jackson, TN $(76 \mathrm{~cm})$, and Shorter, AL $(76 \mathrm{~cm})$ produced higher yields of 'Golden Eye Cream' than 'White Acre' and 'Early Acre' when planted with this narrow spacing (data not shown). Thus, 'Golden Eye Cream' offers the producer greater flexibility in row spacing and planting configurations than the currently used cultivars. As a result of synchronous flowering and pod set, 'Golden Eye Cream' can be harvested mechanically during the fresh green stage using a Pixall Harvester. Because of its large seed size, 'Golden Eye Cream' dry seed are subject to splitting if proper adjustments are not made to the combine at harvest. Because of this splitting, 'Golden Eye Cream' did not score as high as 'White
Acre' or 'Early Acre' in food processing evaluations (canning tests) conducted by University of Arkansas cooperators (data not shown), and therefore may not be suitable for the canning industry. 'Golden Eye Cream' is recommended for use by both fresh market producers and home gardeners for the production of fresh-shell, cream-type peas.

\section{Availability}

An application for plant variety protection has been filed for 'Golden Eye Cream', and the registered seed class has been eliminated. Commercial producers and home gardeners can obtain information on seed availability from the Texas Foundation Seed Service, Texas Agr. Expt. Sta., 11914 Hwy. 70, Vernon, TX 76384 or by phone [(940) 5526226].

\section{Literature Cited}

Dukes, P.D. and R.L. Fery. 1993. Disease reactions of regional cooperative southernpea (cowpea) breeding lines and standard cultivars to southern root knot, 1991 and 1992. Biol. Cult. Tests 8:29.

Fery, R.L. and P.D. Dukes. 1990. Registration of US-432 cowpea (southernpea) germplasm. Crop Sci. 30:428.

Kuhn, C.W., B.B. Brantley, J.W. Demski, and G. Pio-Ribeiro. 1984. 'Pinkeye Purple Hull-BVR', 'White Acre-BVR', and 'Corona' cowpeas. HortScience 19:592.

Morelock, T.E., J.L. Bowers, D.R. Davis, and D.R. Motes. 1992. 'Early Acre': A new southernpea for Arkansas. Ark. Farm Res. 41(3):6-7. 